\title{
PERBEDAAN KEMANDIRIAN REMAJA SMA ANTARA YANG SINGLE FATHER DENGAN SINGLE MOTHER AKIBAT PERCERAIAN
}

I Gusti Ayu Mirah Suwinita dan Adijanti Marheni

Program Studi Psikologi, Fakultas Kedokteran, Universitas Udayana

igamirahs@gmail.com

\begin{abstract}
Abstrak
Struktur keluarga adalah salah satu faktor yang membentuk kemandirian remaja. Masa sekarang tidak jarang ditemui keluarga yang tidak utuh karena perceraian. Keadaan keluarga yang tidak lagi utuh (single parent) tentu mempengaruhi kemandirian remaja. Kemandirian remaja merupakan suatu kemampuan untuk mengatur perilaku dan memutuskan tanpa banyak bergantung pada orangtua (Steinberg, 2002). Tujuan dari penelitian ini adalah melihat perbedaan kemandirian remaja SMA antara yang single father dengan single mother akibat perceraian.

Sebanyak 64 remaja SMA Bali berusia 15 hingga 18 tahun yang memiliki single parent akibat perceraian menjadi subjek dalam penelitian kuantitatif dan pendekatan komparasional ini. Teknik sampling yang digunakan adalah Cluster sampling. Alat ukur yang digunakan adalah skala kemandirian remaja (34 aitem, rxx=0.889). Adapun teknik statistik yang digunakan untuk mengolah data penelitian ini adalah dengan menggunakan uji parametrik independent t-test.

Berdasarkan hasil penelitian, terlihat bahwa tidak ada perbedaan kemandirian yang signifikan antara remaja SMA yang single father dengan single mother akibat perceraian $(\mathrm{t}=1.212)$ dengan signifikansi $\mathrm{p}$ sebesar $0.230(\mathrm{p}>0.05)$.
\end{abstract}

Kata kunci : Kemandirian remaja, single father, single mother.

\begin{abstract}
Structure of the family is one of the factors that builds the independence of adolescents. Nowadays, it is uncommon to find families that are not united due to divorcement. The condition where families are no longer united (single parent) will affect the independence of adolescents. Independence of adolescence is the ability to organize behavior and decision without being dependent on parents (Steinberg, 2002). The purpose of this research is to see the difference of independence between senior high school adolescents with single mother and adolescents with single father due to divorcement.
\end{abstract}

A total of 64 senior high school adolescents in Bali in aged 15-18 years who have single parents due to divorcement were included as subjects in this quantitative research, with comparison approach. The sampling technique that was used in this research was cluster sampling. Measuring instrument used in this research was Independence Scale (34 item, $r x x=0.889$ ). The statistical technique used to process the data of this study is a parametric test of independent $t-$ test.

Based on the outcome of this research, it appears that there is no significant difference between the independence of senior high school adolescents with a single father nor single mother due to divorcement $(\mathrm{t}=1.212)$ with $\mathrm{p}$ equal to $0,230(\mathrm{p}>0,05)$.

Keyword: Autonomy of Adolescence, single father, single mother. 


\section{I.G.A.M. SUWINITA DAN A.MARHENI}

\section{LATAR BELAKANG}

Kemandirian merupakan bagian perkembangan yang penting pada remaja. Remaja diharapkan dapat memiliki kemandirian yang baik sehingga tidak akan tergantung dengan orang lain maupun dengan orangtua. Menurut Retnowati (2007), kemandirian merupakan hasrat yang dimiliki oleh seseorang untuk bersaing agar maju untuk diri sendirinya, mampu mengambil keputusan sendiri dan inisiatif dalam menghadapi masalah yang dihadapi, memiliki kepercayaan diri dalam mengerjakan tugas dan tanggungjawab dalam perbuatannya.

Banyak faktor yang dapat mempengaruhi kemandirian remaja seperti yang dinyatakan oleh Allen (dalam Sinaga, 2010), yaitu jenis kelamin, usia, struktur keluarga, budaya, lingkungan dan keinginan individu untuk bebas. Bila dilihat dari keluarga, tentunya akan ditemukan perbedaan kemandirian bila dilihat struktur suatu keluarga. Keluarga merupakan awal perjalanan hidup manusia dan masyarakat secara keseluruhan. Pada hakekatnya, keluarga merupakan satuan sistem sosial terkecil sebagai inti dari sistem sosial secara keseluruhan (Surya, 2001). Masa sekarang ini terdapat keadaan keluarga yang sangat beragam, baik itu berdasarkan kondisi, anggota keluarga, lingkungan, ataupun latar belakang. Umumnya sebuah keluarga terdiri dari anggota keluarga inti yaitu ayah, ibu dan anak, namun selain itu dalam lingkup keluarga yang lebih besar terdapat pula anggota keluarga lainnya, seperti kakek, nenek, paman, bibi, dan cucu. Dilihat dari kondisi suatu keluarga, bisa dikatakan utuh jika anggota keluarga masih terdiri dari keluarga inti, namun di sisi lain ada pula kondisi dimana suatu keluarga bisa dikatakan tidak utuh, jika hanya terdapat satu orang tua yang sering disebut dengan single parent, yang hanya terdapat seorang ayah (single father) atau hanya terdapat seorang ibu (single mother).

Kondisi ini banyak terjadi di kehidupan masyarakat sekarang ini. Adanya single parent dalam suatu keluarga dapat disebabkan oleh banyak faktor, baik itu pribadi maupun orangtua itu sendiri yang memang memutuskan membesarkan anaknya sendiri, faktor yang tidak dikehendaki seperti meninggal dunia, atau perceraian. Dalam penelitian ini, peneliti akan memfokuskan penelitian untuk single parent yang di sebabkan karena perceraian. Single parent menurut DeGenova (2008), merupakan orangtua yang merawat satu anak atau lebih tanpa adanya dampingan dari pasangan.

Keadaan single parent saat ini bukan merupakan hal yang asing. Diantara beberapa penyebab kondisi single parent tersebut perceraian memiliki angka yang semakin meningkat. Menurut data Direktorat Jendral Badan Peradilan Agama Mahkamah Agung (2011), kurun waktu 2010 ada 285.184 perkara yang berakhir dengan perceraian ke pengadilan agama se-Indonesia dan ini merupakan angka tertinggi sejak 5 tahun terakhir dimana peningkatan ini sebanyak $81 \%$.
Perceraian merupakan kondisi dimana terjadi perpisahan sepasang suami istri yang awalnya dua individu yang tidak saling kenal dan bersatu, kembali menjadi dua manusia yang tidak lagi memiliki hubungan atau keterkaitan moral, sosial dan emosional (Ganjar, 2005). Secara yuridis, perceraian berarti putusnya perkawinan, yang mengakibatkan putusnya hubungan suami istri (Syaifuddin, Turatmiyah, \& Yahanan, 2013).

Perceraian tentunya tidak hanya terjadi pemisahan pada dua individu yang memutuskan untuk bercerai namun juga akan berdampak pada pemisahan secara fisik ataupun emosional pada remaja terhadap salah satu orangtua yang tidak mendapatkan hak asuh atas anak. Hak asuh atas anak tentunya akan diputuskan oleh pengadilan ataupun kesepakatan bersama dari pasangan yang bercerai dan tentunya akan ada single parent. Anak-anak akan diasuh oleh ibu saja (single mother) atau anak-anak akan di asuh oleh ayah saja (single father).

Menurut Santrok (2007), masa remaja merupakan masa perkembangan antara masa kanak-kanak dengan masa dewasa yang melibatkan perubahan-perubahan biologis, kognitif, dan sosial-emosional. Remaja yang berasal dari orang tua yang bercerai lebih rentan mengalami masalah akademis, masalah yang bersifat eksternal seperti kenakalan remaja, dan masalah internal seperti depresi dan kecemasan. Hal ini didukung dengan penelitian yang dilakukan oleh Prihatinningsih (2012) yang menyatakan bahwa remaja yang orangtuanya bercerai mengalami masalah emosi seperti mudah marah, melawan orangtua dan juga mengalami masalah psikologis seperti perasaan terluka, merasa diabaikan dan memiliki perasaan tidak dicintai terus-menerus.

Salah satu tugas perkembangan yang paling penting di masa remaja adalah mengembangkan secara bertahap kemandirian untuk membuat suatu keputusan secara kompeten (Mortimer \& Larson, 2002). Remaja merupakan masa transisi dari masa kanak-kanak ke masa dewasa yang meliputi perubahan secara biologis, kognitif dan sosio-emosional (Santrock, 2007). Lie \& Prasasti (2004) juga memberikan gambaran perkembangan kemandirian remaja dimana remaja yang berusia $15-18$ tahun yang tengah menginjak masa SMA sedang mempersiapkan diri menuju proses pendewasaan. Banyak pilihan yang ada di hadapan para remaja usia $15-18$ tahun dan diharapkan pada usia ini remaja dapat memutuskan pilihannya sendiri tanpa bantuan dari orangtua. Pada masa ini orangtua hanya mengarahkan dan membimbing remaja dalam mempersiapkan diri perjalanan ke masa depan.

Menurut Surya (2001), dalam menghadapi masalahmasalah keluarga single parent, setiap orang tua mempunyai cara dan kiat yang berbeda antara satu dengan yang lainnya, tergantung dari kondisi yang dihadapi oleh masing-maing keluarga single parent. Ada keluarga yang sukses menjalani keadaan single parent bahkan lebih sukses dari keluarga utuh, 


\section{KEMANDIRIAN REMAJA SMA ANTARA YANG SINGLE FATHER DENGAN SINGLE MOTHER}

namun ada juga yang menyerah dengan keadaan sehingga berlanjut dengan kehancuran keluarga.

Pendidikan mengenai kemandirian tentunya berbeda antara ayah dan ibu. Menurut Santrock (2007), interaksi ayah yang mengasihi, mudah berkomunikasi dan dapat diandalkan dan memberikan dukungan serta kepercayaan pada anakanaknya dapat mendukung perkembangan sosial anak. Dalam sebuah penelitian Frank Fustenberg \& Kathleen Haris (dalam Santrock, 2007) mendokumentasikan bahwa pengasuhan ayah dapat membantu anak dalam menghadapi masalah hidupnya. Ibu tentunya akan dikaitkan dengan kualitas positif seperti hangat, tidak mementingkan diri sendiri, bertanggung jawab dan toleran (Martlin dalam Santrock, 2007). Ibu yang berperan sebagai orang tua tunggal memiliki kecenderungan untuk tidak konsisten dalam menegakkan kedisiplinan dan tentu akan mempengaruhi kemandirian anak serta memiliki keterbatasan dalam proses pembentukan kemandirian anak (Retnowati, 2007).

Ibu memiliki kecenderungan kurang sabar melihat anaknya mengerjakan segala sesuatu hal hingga benar, misalnya saja saat anak memakai sepatu sendiri atau memakai pakaian. Karena banyaknya hal yang harus dikerjakan, ibu biasanya selalu ingin membantu anaknya sehingga kemandirian anak terbentuk lebih lama. Remaja yang tinggal dengan ayah akan lebih dididik untuk disiplin dan percaya bahwa anaknya mampu serta bisa belajar dari kesalahannya (Imam, 2013).

Berdasarkan teori-teori yang telah dibaca peneliti dan uraian permasalahan di atas, maka timbul keyakinan dari peneliti bahwa jenis kelamin dari orangtua dalam hal ini single father dengan single mother memiliki pengaruh terhadap perkembangan kemandirian dari remaja serta timbul rasa keingintahuan dari peneliti untuk mengetahui apakah ada perbedaan kemandirian remaja SMA antara yang single father dengan single mother akibat perceraian.

\section{METODE}

\section{Hipotesis Penelitian}

Hipotesis penelitian ini menyatakan bahwa tidak terdapat perbedaan yang signifikan antara kemandirian remaja SMA antara yang single father dengan single mother akibat perceraian.

\section{Variabel dan definisi operasional}

Variabel merupakan gejala yang di persoalkan (Purwanto, 2010). Variabel penelitian merupakan apa yang menjadi titik perhatian dari suatu penelitian (Arikunto dalam Sinaga, 2010). Variabel bebas merupakan variabel yang mempengaruhi atau dapat dikatakan sebagai variabel yang menjadi penyebab perubahan atau timbulnya variabel tergantung (Sugiyono, 2013). Variabel bebas dalam penelitian ini adalah jenis kelamin single parent. Variabel tergantung merupakan variabel yang dipengaruhi atau variabel yang menjadi akibat karena adanya variabel bebas (Sugiyono, 2013). Variabel tergantung dalam penelitian ini adalah kemandirian remaja.

Definisi operasional kemandirian remaja adalah segala hal yang diputuskan berdasarkan apa yang dipikir dan dirasakan oleh diri sendiri, segala sesuatu yang dijalankan tanpa terlalu tergantung pada orang lain, dapat mempertanggungjawabkan dan juga ketika suatu masalah datang dapat mengatasinya.

Definisi operasional remaja single father adalah seorang remaja SMA yang diasuh oleh ayah saja yang diakibatkan oleh perceraian yang tidak menikah lagi dan bertanggungjawab atas kebutuhan finansial keluarga dan menggantikan tugas ibu untuk memenuhi kebutuhan psikologis dari keluarga.

Definisi operasional remaja single mother adalah seorang remaja SMA yang diasuh oleh ibu saja yang diakibatkan oleh perceraian yang tidak menikah lagi dan bertanggungjawab atas kebutuhan psikologis anak dan menggantikan tugas ayah dalam memenuhi kebutuhan finansial keluarga.

\section{Responden penelitian}

Populasi adalah wilayah generalisasi yang terdiri atas obyek atau subjek yang memiliki kualitas dan karakteristik tertentu yang peneliti ditetapkan untuk dipelajari dan kemudian akan ditarik kesimpulannya (Sugiyono, 2012). Populasi dalam penelitian ini adalah seluruh remaja SMA Negeri di Bali yang memiliki Single Parent akibat perceraian dimana memiliki karakteristik yaitu mempunyai salah satu dari single father atau single mother akibat perceraian dan tidak/ belum menikah lagi, tinggal dengan salah satu single parent, dan remaja SMA yang berusia 15-18 tahun

\section{Teknik Pengambilan Sampel}

Mengingat tidak semua populasi dapat dipilih sebagai sampel dan penarikan sampel berdasarkan pertimbanganpertimbangan tertentu, maka teknik sampling yang digunakan yaitu dengan prosedur probability sampling. Probability sampling atau disebut juga dengan sampling peluang merupakan teknik sampling yang memberikan peluang yang sama terhadap setiap anggota pada populasi untuk terpilih menjadi sampel (Purwanto, 2010). Dengan menggunakan prosedur probability sampling, teknik yang digunakan untuk mengambil sampel adalah dengan teknik cluster sampling. Cluster sampling merupakan teknik sampling yang digunakan 


\section{I.G.A.M. SUWINITA DAN A.MARHENI}

apabila populasi dari sampel berkluster atau ber-area (Purwanto, 2010). Dengan menggunakan prosedur probability sampling, teknik yang digunakan untuk mengambil sampel adalah dengan teknik cluster sampling. Cluster sampling merupakan teknik sampling yang digunakan apabila populasi dari sampel berkluster atau ber-area (Purwanto, 2010).

Menurut data terakhir pada Badan Pusat Statistik (BPS) Provinsi Bali tahun 2013, di provinsi Bali terdapat 75 sekolah menengah umum negeri yang terbagi ke dalam 9 kabupaten dan kota. 9 kabupaten akan di acak dan terpilih sebagai area penelitian. Jumlah anggota dalam populasi dalam penelitian ini tidak diketahui, sehingga peneliti mengacu pada pendapat Roscoe dalam Sugiyono (2012), yaitu bila sampel dibagi dalam kategori (misalnya: pria-wanita, pegawai negeriswasta dan lain-lain) maka jumlah anggota sampel setiap kategori minimal 30. Jadi, penelitian perbedaan kemandirian remaja SMA antara yang single father dengan single mother akibat perceraian yang terdiri dari dua kategori menggunakan minimal sampel sebanyak 60 .

\section{Tempat Penelitian}

Melalui hasil pengundian pada proses pengambilan sampel terhadap kesembilan kabupaten atau kotamadya yang berada di Bali, terpilihlah kabupaten Badung sebagai area terpilih. Jadi, pengambilan data dilakukan di seluruh SMA negeri se-Kabupaten Badung dengan jumlah Sekolah Negeri di Kabupaten Badung sebanyak 8 sekolah.

\section{Alat ukur pengumpulan data}

Penelitian ini menggunakan skala kemandirian remaja sebagai instrumen utama dalam proses pengumpulan data. Skala kemandirian remaja merupakan data utama dalam penelitian ini karena merupakan respon langsung yang didapatkan dari responden penelitian. Skala kemandirian remaja memuat 3 aspek yaitu emotional, behavioral, dan value yang telah dibuat sendiri oleh peneliti.

Skala kemandirian remaja dengan model skala Likert yang dimodifikasi terdiri dari empat pilihan jawaban, yaitu: Sangat Setuju (SS), Setuju (S), Tidak Setuju (TS) dan Sangat Tidak Setuju (STS). Pada tiap skala memiliki nilainya masingmasing dimana pada item favorable Sangat Setuju (SS) diberi nilai 4, Setuju (S) diberi nilai 3, Tidak Setuju (TS) diberi nilai 2 dan Sangat Tidak Setuju (STS) diberi nilai 1. Begitu pula sebaliknya pada item unfavorable masing-masing skala memiliki nilai, Sangat Setuju (SS) diberi nilai 1, Setuju (S) diberi nilai 2, Tidak Setuju (TS) diberi nilai 3, dan Sangat Tidak Setuju (STS) diberi nilai 4. Tingkat kemandirian remaja dikatakan tinggi apabila nilai skala semakin tinggi. Begitu pula sebaliknya, apabila nilai skala rendah maka kemandirian remaja juga semakin rendah.
Kedua alat ukur tersebut diuji validitas dan reliabilitasnya. Pengujian terhadap validitas isi skala dilakukan melalui profesional judgment, sedangkan uji kesahihan butir aitem diukur melalui pengujian konsitensi internal dengan melihat besarnya koefisien korelasi aitem total (rix). Uji kesahihan butir aitem dengan cara membuang item-item yang memiliki nilai korelasi aitem total dibawah 0,30 (Azwar, 2012). Sedangkan uji reliabilitas dilakukan dengan mengunakan pendekatan single trial administration (Azwar, 2012) dimana item-item dalam penelitian ini memiliki reliabilitas tinggi jika memiliki koefisien $>0,60$. Terdapat 26 aitem yang gugur dari 34 aitem yang diuji. Koefisien reliabilitas alpha sebesar 0,889 menunjukkan bahwa skala ini mampu mencerminkan $88,9 \%$ variasi yang terjadi pada skor murni subjek yang bersangkutan. Skala pengukuran ini tergolong mempunyai daya keterandalan yang memuaskan.

\section{Metode pengumpulan data}

Setelah peneliti mendapatkan ijin untuk melakukan penelitian melalui surat dengan nomer 01 p/UN.14.2/PS.4/2014, proses penelitian mulai dilaksanakan pada tanggal 10 Maret 2014 - 25 April 2014 dengan mendatangi seluruh Sekolah Menengah Atas Negeri di kabupaten Badung dan dilakukan bersamaan dengan pelaksanaan uji coba alat ukur. Adapun nama-nama seluruh sekolah negeri yang didatangi peneliti adalah SMA Negeri 1 Kuta Utara, SMA Negeri 1 Kuta, SMA Negeri 2 Kuta, SMA Negeri 1 Kuta Selatan, SMA Negeri 1 Mengwi, SMA Negeri 2 Mengwi, SMA Negeri 1 Abiansemal, dan SMA Negeri 1 Petang.

Pada setiap sekolah, peneliti memasuki semua kelas yang ada pada sekolah bersangkutan dan memberikan skala kemandirian remaja sebanyak jumlah remaja SMA yang ada di kelas. Peneliti juga meminta agar subjek memberi imbuhan kelas dan number absen pada pojok kanan skala sebagai salah satu cara identifikasi subjek oleh peneliti untuk mencari subjek yang sesuai. Setelah skala kemandirian diisi dan dikumpulkan, peneliti menyortir mana saja skala yang dapat digunakan lalu menghubungi lagi remaja SMA dengan mengecek kelas dan number absen dari remaja SMA untuk menanyakan kembali apakah subjek memiliki single parent karena bercerai atau karena hal lain.

Skala yang berhasil dikumpulkan dari sekolahsekolah di atas adalah sebanyak 73 skala. Sebanyak 9 skala tidak dapat di analisis karena terdapat beberapa item yang terlewatkan dalam pengisian oleh subjek. Hanya 64 skala yang dapat digunakan untuk dilanjutkan ke tahap analisis dari seluruh skala yang sudah dikumpulkan.

Teknik analisis data

Metode analisis data yang dilakukan dalam penelitian ini adalah dengan menggunakan uji independent sample t-test. 


\section{KEMANDIRIAN REMAJA SMA ANTARA YANG SINGLE FATHER DENGAN SINGLE MOTHER}

Teknik statistik uji t dilakukan karena menimbang kebutuhan studi ini yang hendak melakukan komparasi terhadap dua kelompok sampel penelitian dan jenis data dari penelitian ini yakni nominal dan interval. Tujuan uji independent sample ttest adalah untuk mengetahui perbedaan mean antara dua populasi dengan melihat rata-rata dua sampelnya (Santoso, 2005).

Sebelum melakukan uji statistik independent sample t-test, perlu dilakukan uji asumsi, berupa uji normalitas dan uji homogenitas sebagai syarat sebelum dilakukan uji statistik. Dalam penelitian ini uji normalitas menggunakan uji Komolgorov-Smirnov dengan tingkat signifikansi $\geq 0,05$. Peneliti menguji normalitas data menggunakan program SPSS versi 15. Uji homogenitas digunakan untuk memastikan apakah kelompok-kelompok yang dibandingkan dalam penelitian ini merupakan kelompok yang homogen (Purwanto, 2010). Pengukuran homogenitas dilakukan dengan analisis varian melalui Levene's Test, dengan tingkat signifikansi $>0,05$ data bersifat homogen dan <0,05 data bersifat tidak homogen. Peneliti menguji homogenitas data menggunakan program SPSS versi 15.

\section{HASIL PENELITIAN}

Pelaksanaan pengambilan data penelitian yang berlangsung pengambilan data ini dilaksanakan pada tanggal 10 Maret 2014 - 25 April 2014 dengan 64 responden, yang merupakan remaja SMA. Responden penelitian adalah remaja SMA yang memiliki single parent dengan rentang usia 15-18 tahun. Secara lebih rinci data responden dijelaskan dalam tabel 1.

Tabel 1. Profil Responden

\begin{tabular}{cccc}
\hline Karakteristik & Kategorisasi & Jumlah & Persentase \\
\hline Usia & 15 tahun & 7 & $10.94 \%$ \\
& 16 tahun & 22 & $34.37 \%$ \\
& 17 tahun & 15 & $23.44 \%$ \\
\multicolumn{2}{c}{ Total 18 tahun } & 20 & $31.25 \%$ \\
Jenis Kelamin $\quad$ Laki-laki & 64 & $\mathbf{1 0 0} \%$ \\
& Terempuan & 28 & $43.75 \%$ \\
Total & 36 & $56.25 \%$ \\
& 64 & $\mathbf{1 0 0 \%}$ \\
\hline Struktur Orangtua & Single Father & 32 & \\
& Single Mother & 32 & $50 \%$ \\
Total & $\mathbf{6 4}$ & $\mathbf{1 0 0 \%}$ \\
\hline
\end{tabular}

Uji normalitas dilakukan untuk mengetahui apakah populasi data distribusi normal atau tidak. Pengujian normalitas data dalam penelitian ini menggunakan Kolmogorov-Smirnov.
Tabel 2. Uji Normalitas

\begin{tabular}{ccc}
\hline & $\begin{array}{c}\text { Remaja dengan } \\
\text { Single Father }\end{array}$ & $\begin{array}{c}\text { Remaja dengan } \\
\text { Single Mother }\end{array}$ \\
\hline $\mathbf{N}$ & 32 & 32 \\
Kolmogorov-Smirnov & 0.413 & 0.749 \\
$\mathbf{Z}$ & 0.996 & 0.643 \\
$\begin{array}{c}\text { Asymp. Sig. (2-tailed) } \\
\text { Status }\end{array}$ & $\begin{array}{c}\text { Terdistribusi } \\
\text { normal }\end{array}$ & $\begin{array}{c}\text { Terdistribusi } \\
\text { normal }\end{array}$ \\
\hline
\end{tabular}

Sebaran data pada remaja dengan Single Father memiliki nilai signifikansi dengan probabilitas (p) 0,996 atau mempunyai probabilitas di atas 0,05 ( $\mathrm{p}>0,05)$. Hal ini menunjukkan bahwa sebaran data pada remaja dengan Single Father berdistribusi normal. Sebaran data pada remaja dengan Single Mother memiliki nilai signifikansi dengan probabilitas (p) 0,643 atau mempunyai probabilitas di atas 0,05 ( $>>0,05)$. Hal ini menunjukkan bahwa sebaran data pada remaja dengan Single Mother berdistribusi normal.

Uji asumsi berikutnya adalah uji homogenitas. Pengujian homogenitas dilakukan dengan menggunakan Levene's test.

Tabel 3. Uji Homegenitas

\begin{tabular}{cc}
\hline Levene's Test for Equality of Variances \\
\hline $\mathbf{F}$ & Sig. \\
0.411 & 0.524 \\
\hline
\end{tabular}

Sampel dapat dikatakan homogen apabila memiliki nilai signifikansi $\mathrm{p}>0.05$ dan didapatkan bahwa nilai $\mathrm{p}=$ $0.524, \mathrm{p}>0.05$ sehingga dapat diartikan bahwa distribusi skorskor pada kemandirian remaja varians skornya homogen.

Tabel 4. Hasil Uji T

\begin{tabular}{ccc}
\hline \multicolumn{3}{c}{ t-test for Equality of Means } \\
$\mathrm{T}$ & Sig. (2-tailed) & Mean Difference \\
1.212 & 0.230 & 3.063 \\
\hline
\end{tabular}

Setelah kedua syarat untuk melakukan analisis data secara parametrik pada penelitian ini telah dipenuhi, dilanjutkan dengan menggunakan metode analisis independent samples t-test menggunakan program SPSS 15.0. Test ini lakukan untuk melihat apakah ada perbedaan rata-rata (mean) antara dua populasi, dengan melihat rata-rata dua sanpelnya. Pada tabel 2, dapat dilihat bahwa diperoleh nilai signifikansi $\mathrm{p}$ sebesar 0.230 atau $(\mathrm{p}>0,05)$ pada taraf signifikan 0,05 . Oleh karena itu dapat dikatakan tidak terdapat perbedaan kemandirian antara kepribadian kelompok remaja SMA dengan single father dengan remaja dengan single mother.

Tabel 5. Kategori Kemandirian Remaja Ditinjau dari Struktur Orangtua Single Father dan Single Mother

\begin{tabular}{ccccc}
\hline Variabel & \multicolumn{4}{c}{ Struktur Orangtua } \\
\hline $\begin{array}{c}\text { Kemandirian } \\
\text { Remaja }\end{array}$ & $\begin{array}{c}\text { Remaja } \\
\text { dengan Single } \\
\text { Father }\end{array}$ & Persentase & $\begin{array}{c}\text { Remaja } \\
\text { dengan Single } \\
\text { Mother }\end{array}$ & Persentase \\
Tinggi & 21 & $65.62 \%$ & 15 & $46.87 \%$ \\
Sedang & 11 & $34.38 \%$ & 17 & $53.13 \%$ \\
Rendah & 0 & $0 \%$ & 0 & $0 \%$ \\
Jumlah & $\mathbf{3 2}$ & $\mathbf{1 0 0} \%$ & $\mathbf{3 2}$ & $\mathbf{1 0 0 \%}$ \\
\hline
\end{tabular}


Berdasarkan tabel 5 di atas, dapat dilihat bahwa kemandirian remaja kategori tinggi berasal dari kelompok remaja single father yaitu sebanyak $65.62 \%$, sedangkan pada single mother sebanyak $46.87 \%$. Kemandirian remaja dengan kategori sedang terbanyak terlihat pada kelompok remaja dengan single mother sebanyak $53.13 \%$, sedangkan dari kelompok remaja dengan Single father sebanyak $34.38 \%$. Kategori rendah tidak terlihat dari kelompok remaja baik single father maupun single mother dimana pada ketegori ini tidak terdapat remaja dengan nilai yang tergolong dalam kategori kemandirian rendah atau dengan persentase $0 \%$.

\begin{tabular}{ccccc}
\multicolumn{5}{c}{ Tabel 6. Kategori Kemandirian Remaja Ditinjau dari Jenis Kelamin } \\
\hline Variabel & \multicolumn{4}{c}{ Jenis Kelamin } \\
\hline Kemandirian & $\begin{array}{c}\text { Remaja Laki- } \\
\text { Remaja }\end{array}$ & Persentase & $\begin{array}{c}\text { Remaja } \\
\text { laki }\end{array}$ & Perempuan \\
Tinggi & 15 & $53.58 \%$ & 19 & $52.78 \%$ \\
Sedang & 13 & $46.42 \%$ & 17 & $47.22 \%$ \\
Rendah & 0 & $0 \%$ & 0 & $0.00 \%$ \\
Jumlah & $\mathbf{2 8}$ & $\mathbf{1 0 0 \%}$ & 36 & $\mathbf{1 0 0} \%$ \\
\hline
\end{tabular}

Berdasarkan tabel 6 di atas, dapat dilihat bahwa kategori kemandirian tinggi berasal dari kelompok remaja laki-laki dengan persentase $53.58 \%$ dibandingkan dengan remaja perempuan dengan persentase $52.78 \%$. Kategori sedang berasal dari kelompok remaja perempuan dengan persentase $47.22 \%$ dibandingkan dengan kelompok remaja laki-laki dengan presentase $46.42 \%$. Kategori rendah tidak terlihat dari kelompok remaja baik single father maupun single mother dimana pada ketegori ini tidak terdapat remaja dengan nilai yang tergolong dalam kategori kemandirian rendah atau dengan persentase $0 \%$.

Tabel 7. Kategori Kemandirian Remaja Ditinjau dari Jenis Kelamin pada Setiap Kelompok Single Parent

\begin{tabular}{|c|c|c|c|c|c|c|}
\hline \multirow{3}{*}{$\begin{array}{c}\text { Variabel } \\
\text { Single } \\
\text { parent }\end{array}$} & \multicolumn{6}{|c|}{ Kemandirian Remaja } \\
\hline & \multirow{4}{*}{$\begin{array}{l}\text { Single } \\
\text { Father }\end{array}$} & & Tinggi & Sedang & Rendah & Total \\
\hline & & Remaja & 10 & 4 & 0 & 14 \\
\hline & & Laki-laki & & & & \\
\hline & & Persentase & $71.43 \%$ & $28.57 \%$ & $0 \%$ & $100 \%$ \\
\hline & \multirow{7}{*}{$\begin{array}{l}\text { Single } \\
\text { Mother }\end{array}$} & Remaja & 11 & 7 & 0 & 18 \\
\hline & & Persentase & $61.11 \%$ & $12.6 \%$ & $0 \%$ & $100 \%$ \\
\hline & & Remaja & 5 & 9 & 0 & 14 \\
\hline & & Laki-laki & & & & \\
\hline & & Persentase & $35.72 \%$ & $64.28 \%$ & $0 \%$ & $100 \%$ \\
\hline & & $\begin{array}{c}\text { Remaja } \\
\text { Perempuan }\end{array}$ & 8 & 10 & 0 & 18 \\
\hline & & Persentase & $44.44 \%$ & $55.56 \%$ & $0 \%$ & $100 \%$ \\
\hline
\end{tabular}

Berdasarkan tabel 7, dapat dilihat bahwa pada remaja laki-laki dengan kategori tinggi lebih banyak berasal dari kelompok single father dibandingkan dengan remaja laki-laki dari kelompok single mother yaitu $71.43 \%$ pada kelompok single father dan $35.72 \%$ pada kelompok single mother. Remaja perempuan dengan kategori tinggi juga berasal dari kelompok single father dibandingkan dengan remaja perempuan dari kelompok single mother yaitu $61.11 \%$ pada kelompok single father dan $44.44 \%$ dari kelompok single mother.

\section{PEMBAHASAN DAN KESIMPULAN}

Berdasarkan hasil analisis perbandingan dengan menggunakan independent samples t-test, didapat bahwa nilai signifikansi $\mathrm{p}$ adalah sebesar 0,230 ( $\mathrm{p}>0,05)$. Hal ini menunjukkan bahwa tidak terdapat perbedaan yang signifikan antara kemandirian remaja SMA yang single father dengan single mother akibat perceraian.

Berdasarkan uji hipotesis yang telah dilakukan, remaja dengan orangtua single parent dapat dikatakan samasama mandiri. Hal ini dapat terjadi dikarenakan selain faktor struktur keluarga masih ada faktor lain yang dapat mempengaruhi kemandirian remaja. Seperti yang dikatakan oleh Allen dkk (dalam Sinaga, 2010), faktor yang dapat mempengaruhi kemandirian remaja yaitu jenis kelamin, usia remaja, struktur keluarga, budaya, lingkungan dan juga keinginan dari remaja sendiri untuk menjadi mandiri. Walaupun cara pengasuhan yang berbeda antara single father dengan single mother, remaja mampu mengembangkan kemandirianan dengan dukungan positif yang diberikan oleh orangtua single parent. Hal ini juga ditegaskan oleh Will dalam LaFreniere (2000) yang mengatakan bahwa dukungan dari orangtua dapat mendorong afektif positif pada remaja karena remaja akan percaya bahwa saat mereka membutuhkan, orangtua selalu ada dan tetap mendukung.

Berdasarkan hasil kategorisasi skor skala kemandirian remaja, menunjukkan bahwa kelompok remaja single father sejumlah 32 subjek dan kelompok remaja single mother sejumlah 32 subjek. Subjek yang memiliki skor kemandirian remaja yang tinggi dengan single father berjumlah 21 subjek dan subjek dengan single mother berjumlah 15 subjek, Dari jumlah total subjek, tidak terdapat subjek yang memiliki skor kemandirian remaja yang rendah baik dari kelompok remaja single mother maupun kelompok remaja single father, sehingga dapat dikatakan subjek yang memiliki skor kemandirian yang rendah tidak berasal dari manapun dan remaja dengan kategori skor kemandirian tinggi lebih banyak dari kelompok remaja dengan single father. Kedisiplinan dan kepercayaan diri merupakan salah satu hal yang diyakini menjadi dasar terbentuknya kemandirian (Retnowati, 2007). Sosok ayah lebih mengajarkan tentang kedisiplinan dan sosok ibu yang cenderung kurang konsisten dalam menegakkan kedisiplinannya (Frankl, 1972). Dalam kasus perceraian, seorang ibu cenderung lebih merasa bersalah karena perceraiannya sehingga berbuat banyak hal untuk anak hingga membiarkan anak mengatur kehidupannya. Upaya yang terlalu berlebihan yang dilakukan oleh seorang ibu bisa menyebabkan suatu masalah jika ibu merasa terlalu bertanggung jawab atas anaknya. Peran ganda sering diupayakan seorang ibu yakni sekaligus menjadi seorang ayah sehingga banyak mengambil tanggung jawab dan anak sedikit memikul tanggung jawab (Balson, 1999).

Berdasarkan uji statistik yang telah dilakukan, kategori kemandirian remaja dengan kategori kemandirian 


\section{KEMANDIRIAN REMAJA SMA ANTARA YANG SINGLE FATHER DENGAN SINGLE MOTHER}

tinggi sebanyak 33 orang dengan persentase $51.56 \%$, remaja dengan kategori sedang sebanyak 31 orang dengan persentase $48.44 \%$, dan remaja dengan kategori kemandirian rendah tidak berasal dari kelompok single father maupun single mother. Dapat dilihat bahwa remaja dengan single parent lebih banyak berada pada kategori kemandirian tinggi. Hal ini dapat terjadi dengan adanya kesadaran diri yang cukup baik dari remaja yang memiliki orang tua single parent dalam manjalankan tanggungjawab dan peran mereka masing-masing (Sinaga, 2010). Remaja yang dapat memaknai hidupnya dengan positif juga akan memiliki kemandirian yang baik (Erfiana, 2013). Remaja yang lebih mandiri akan lebih percaya diri sehingga dapat melakukan penyesuaian diri dengan baik (Bernasih dalam Sukaesih, 2001).

Bedasarkan analisis statistik yang telah dilakukan, dapat dilaporkan bahwa sebagian besar subjek dengan kategori kemandirian tinggi berasal dari remaja laki-laki, dengan persentase sebanyak $53.58 \%$ dibandingkan dengan remaja perempuan dengan presentase $52.78 \%$. Namun disisi lain remaja dengan kemandirian sedang berasal dari kelompok remaja perempuan dengan presentase $47.22 \%$ sedangkan pada kelompok remaja laki-laki dengan persentase $46.42 \%$. Menurut Santrock (2007), pemberian kebebasan di masa remaja lebih diberikan pada remaja laki-laki dibandingkan remaja perempuan. Remaja perempuan lebih mengalami kecemasan apabila mengalami kondisi yang sulit dan remaja laki-laki lebih menunjukkan perilaku agresif (Nasution, 2007). Dalam keluarga bercerai, kecenderungan untuk melepaskan diri dari keluarga lebih banyak dijumpai pada remaja laki-laki dibandingkan dengan remaja perempuan. Remaja laki-laki lebih dituntut untuk mandiri dan remaja perempuan memiliki ketergantungan yang lebih stabil (Allen dkk dalam Sinaga, 2010).

Berdasarkan kategorisasi jenis kelamin remaja pada setiap kelompok single parent dapat dilihat bahwa remaja lakilaki dengan kategori tinggi lebih banyak berasal dari kelompok single father dibandingkan dengan remaja laki-laki dari kelompok single mother, dengan persentase $71.43 \%$ pada kelompok single father dan $35.72 \%$ pada kelompok single mother. Remaja perempuan dengan kategori tinggi juga berasal dari kelompok single father dibandingkan dengan remaja perempuan dari kelompok single mother, dengan persentase $44.44 \%$ pada kelompok single mother dan $61.11 \%$ dari kelompok single father. Berdasarkan hasil ini dapat dilaporkan bahwa dengan kondisi bercerai, remaja baik dengan jenis kelamin laki-laki maupun perempuan dapat mencapai kemandirian tinggi dengan pengasuhan ayah. Remaja yang tinggal dengan ayah akan dididik untuk lebih disiplin dan ayah memberikan kepercayaan bahwa anak mampu dan dapat belajar dari kesalahan (Imam, 2013). Menurut Santrock (2007), remaja laki-laki dapat menyesuaikan diri dengan pengasuhan ayah dan remaja perempuan dapat menyesuaikan diri dengan pengasuhan ibu. Hal ini dapat dilihat pada remaja laki-laki dengan kemandirian tinggi berasal dari kelompok single father. Pada remaja perempuan juga dapat dilihat bahwa ketegori kemandirian sedang berada pada kelompok single mother yaitu dengan presentase $55.56 \%$ pada single mother dan $12.6 \%$ pada kelompok single father.

Usia remaja juga mempengaruhi dalam pembentukan kemandirian. Pada penelitian ini remaja berusia 15 tahun - 18 tahun. Remaja berusia 15 tahun sebanyak 7 orang dengan persentase $10.94 \%$, remaja dengan usia 16 tahun sebanyak 22 orang dengan persentase $34.37 \%$, remaja dengan usia 17 tahun sebanyak 15 orang dengan persentase $23.44 \%$ dan remaja dengan umur 18 tahun sebanyak 20 orang dengan persentase $31.25 \%$. Pada usia 15 tahun - 18 tahun, remaja berasa pada bangku sekolah menengah atas. Menurut Lie \& Prasasti (2004), usia 15 tahun - 18 tahun merupakan usia remaja tengah mempersiapkan diri menuju proses mendewasakan diri. Pada masa ini diharapkan agar remaja dapat membuat sendiri pilihan sendiri bagi dirinya tanpa tergantung pada orangtua. Tahap ini remaja juga dalam kondisi kebingungan dan ragu dalam berbagai pilihan, peka atau perduli, ramai-ramai atau menyendiri, optimis atau pesimis, dan sebagainya (Monks, 1999).

Hurlock dalam Ali (2004) menjelaskan bahwa tugas perkembangan remaja adalah mencapai kemandirian baik secara emosional maupun ekonomi. Hal ini juga diungkapkan oleh Havighurst (dalam Dewinda dan Racmawati, 2005), ada salah satu tugas perkembangan remaja yaitu mencapai kebebasan emosional dari orangtua dan orang dewasa lainnya dengan tingkah laku yang dapat dipertanggungjawabkan. Dapat dijelaskan, pada usianya remaja sudah dituntut untuk memiliki kemandirian tanpa bergantung pada orangtua atau orang dewasa lain di sekitarnya.

Berdasarkan analisis kemandirian remaja berdasarkan kelompok single father dan kelompok single mother, jenis kelamin dan jenis kelamin berdasarkan tiap kelompok single parent dapat dikatakan bahwa remaja dengan keluarga bercerai lebih banyak berada pada kategori kemandirian tinggi. Banyak faktor yang mempengaruhi kemandirian remaja termasuk jenis kelamin, usia, struktur keluarga, budaya, lingkungan dan keinginan untuk bebas (Allen dkk dalam Sinaga, 2010). Remaja yang diasuh oleh single parent karena perceraian baik oleh ayah maupun ibu, mengalami berbagai konflik psikologis. Konflik-konflik tersebut tidak hanya menghambat tugas-tugas perkembangannya bahkan dapat membuat konsep dirinya menjadi negatif (Zahroh, 2005).

Dengan demikian, setelah melalui prosedur penelitian dan analisis data yang sesuai, penelitian ini telah mencapai tujuannya yaitu mampu melihat apakah ada perbedaan yang signifikan atau tidak kemandirian remaja SMA antara yang single father dengan single mother akibat perceraian. Analisis 
komputasi statistik telah berhasil membuktikan bahwa dalam penelitian ini, tidak terlihat perbedaan secara signifikan pada kemandirian remaja dengan single father dengan single mother. Selain itu terdapat keterbatasan dalam penelitian ini, dimana peneliti tidak melihat lama waktu remaja mengalami keadaan single parent dan keadaan lingkungan dari remaja dengan single parent.

Saran praktis yang dapat dipertimbangkan berdasarkan hasil penelitian yaitu bagi remaja dengan single parent baik remaja yang memiliki single father maupun remaja yang memiliki single mother, dapat mempertahankan sikap positif yang dapat mempertahankan kemandiriannya, mengerti keadaan dari orangtua yang sudah tidak bersama lagi yang dikarenakan oleh perceraian dan tetap menjaga kedekatan dengan orangtua manapun baik ayah atau itu walau tidak tinggal bersama. Walaupun tidak ada salah satu orangtua, diharapkan remaja tetap mau berbagi dengan orangtuanya dan saling melengkapi. Misalnya dengan membantu pekerjaan rumah, mengerjakan tugas sekolah dengan baik dan mengatasi masalahnya sendiri tanpa terlalu membebani orangtua, tetapi tetap meminta bantuan saat tidak mampu mengatasi. Saran praktis bagi orangtua single parent yaitu diharapkan bagi orangtua single parent untuk tetap mengawasi anak namun tidak melakukan pengekangan dan tidak membebaskan anak. Orangtua single parent diharapkan tidak memaksakan diri untuk menggantikan peran sebagai orangtua pengganti dan tetap mengutamakan menjalin komunikasi yang baik dengan remaja. Orangtua single parent juga tidak membuat remaja terpaksa menggantikan peran orangtua namun tetap memposisikan remaja sebagai seorang anak dan berbagi layaknya sebagai teman.

Saran bagi peneliti selanjutnya yang dapat dipertimbangkan berdasarkan hasil penelitian yaitu (1) Memperbesar jumlah subjek penelitian dan daerah pengambilan data diperluas agar data yang diperoleh semakin terpercaya dan bervariasi, serta dapat menggambarkan kemandirian remaja dengan single parent. (2) Meneliti variabel lain yang tidak menjadi fokus dalam penelitian ini, namun bila dilihat secara teori memberi distribusi penting dalam kemandirian remaja dengan single parent. (3) Selain itu terdapat keterbatasan dalam penelitian ini, dimana peneliti tidak melihat lama waktu remaja mengalami keadaan single parent dan keadaan lingkungan dari remaja dengan single parent.

\section{DAFTAR PUSTAKA}

Ali, M., \& Asrori, M. (2009). Psikologi Remaja Perkembangan Peserta Didik. Jakarta: Bumi Aksara.

Ali, M., \& Asrori, M. (2011). Psikologi Remaja. Jakarta: PT Bumi Aksara.

Astuti, R. D. (2006). Pengaruh pola asuh orangtua terhadap kemandirian siswa dalam belajar pada siswa kelas XI SMA
Negeri Sumpiuh Kabupaten Banyumas tahun pelajaran 2005/2006.

Aulia, S. (2010). Kemandirian remaja yang memiliki orang tua yang bercerai. Diakses Februari 19, 2013, dari http://repository.gunadarma.ac.id/ bitstream/123456789/3587/1/JURNAL.pdf

Azwar, S. (2005). Tes Prestasi. Yogyakarta: Pustaka Pelajar.

Azwar, S. (2010). Dasar-dasar Psikometri. Yogyakarta: Pustaka Pelajar Offset.

Balson, M. (1999). Becoming Better Parents Edisi Ke-4. (S. Alberta, Trans.) Jakarta: Grasindo.

Baumrind, D. (2005). Patterns of parental authority and adolescent autonomy. New Direction and Adolescent Development, 61-69.

Berk, L. E. (2012). Development Through The Lifespan. Yogyakarta: Pustaka Pelajar.

BPS. (2013). Bali dalam angka 2013. BPS Provinsi Bali, Bidang integrasi pengolahan dan diseminasi statistik. Bali: BPS Provinsi Bali.

Erfiana, L. R. (2013, Juli). Hubungan antara kebermanaan hidup dengan kemandirian pada remaja. Diakses Mei 26, 2014, dari

http://journal.uad.ac.id/index.php/EMPATHY/article/view/ 1541

Frankl, V. E. (1972). Man's Search For Meaning: An Introduction to Logotherapy. Boston: Beacon Press.

Hadi, S. (2000). Statistik (Vol. Jilid 1). Yogyakarta: ANDI.

Imam, S. (2013, Desember 17). 5 Kelebihan Ayah dalam Mendidik Anak. Diakses Maret 3, 2014, dari Kesekolah.com: www.kesekolah.com/artikel-dan-berita/pendidikan/5kelebihan-ayah-dalam-mendidik-anak.html

Jahja, Y. (2011). Psikologi Perkembangan. Jakarta: Kencana.

Keluarga. (2012, November 18). Diakses Maret 19, 2013, dari Wikipedia: id.m.wikipedia.org/wiki/Keluarga

LaFreniere, P. J. (2000). Emotional Development (A Biosocial Perspective). USA: Wadsworth.

Lie, A., \& Sarah, P. (2004). 101 cara membina kemandirian dan tanggung jawab anak. Jakarta: Elex Media Komputindo.

Monks, F. \&., AMP, \& Haditono. (1999). Psikologi Perkembangan: Pengantar dalam Berbagai Bagiannya. (S. R. Haditono, Trans.) Yogyakarta: Gadjah Mada University.

Nasution, I. K. (2007, Agustus). Stress pada remaja. Diakses Januari 21, 2014, dari http://library.usu.ac.id/download/fk/132316815(1).pdf

Papalia, D. E., Olds, S. W., \& Feldman, R. D. (2009). Human Development (Vol. Eleventh Edition). New York: McGraw-Hill Companies.

Prihatinningsih, S. (2012). Jurnal juvenile delinquency (kenakalan remaja) pada remaja putra korban perceraian orang tua. Diakses Januari 25, 2014, dari http://repository.gunadarma.ac.id/bitstream/123456789/105 9/1/10504177.pdf

Purwanto. (2010). Metodologi Penelitian Kuantitatif. Yogyakarta: Pustaka Pelajar.

Rachmawati, M. A. (2005). Hubungan antara konformitas teman sebaya dengan kemandirian pada remaja SLTA. Diakses Mei 2004, dari 


\section{KEMANDIRIAN REMAJA SMA ANTARA YANG SINGLE FATHER DENGAN SINGLE MOTHER}

http://psychology.uii.ac.id/images/stories/jadwal_kuliah/nas kah-publikasi-04320212.pdf

Retnowati, Y. (2007). Pola komunikasi orang tua tunggal dalam membentuk kemandirian anak (kasus di kota yogyakarta). Diakses Februari 19, 2013, dari http://repository.ipb.ac.id/bitstream/handle/123456789/106 28/2007yre.pdf?...2

Rice, F. P., \& Dolgin, K. G. (2002). The Adolescent (Development, Relationship, and Culture). Boston: A Pearson Education Company.

Russell, S., \& Bakken, R. J. (2002, Februari). Development of autonomy in adolescence. Diakses Februari 2014, dari http://www.ianrpubs.unl.edu/epublic/ archive/g1449/build/g1449.pdf

Santrock, J. W. (2007). Remaja (Vol. 11). Jakarta: Erlangga.

Santrock, J. W. (2007). Remaja (Vol. 1). Jakarta: Erlangga.

Sarwono, J. (2006). Metode Penelitian Kuantitatif dan Kualitatif. Yogyakarta: Graha Ilmu.

Sarwono, S. W. (2011). Psikologi Remaja. Jakarta: PT Rajagrafindo Persada.

Setyorini, A. V. (2007). Dampak psikologis remaja putri yang hidup dalam keluarga single - parent father bercerai. Diakses Februari 19, 2013, dari http://eprints.unika.ac.id/1467/

Sinaga, J. M. (2010). Perbedaan kemandirian antara remaja yang memiliki orangtua single parent dengan remaja yang memiliki orangtua utuh. Diakses Februari 19, 2013, dari http://repository.usu.ac.id/handle/123456789/26287

Steinberg. (2002). Adolescence (6th ed.). USA: McGraw Hill Higher Education.

Steinberg, L., Cauffman, E., Woolard, J., Grahan, S., \& Banich, M. (2009, Oktober). Are adolescents less mature than adults? : minors' access to abortion, the juvenile death penalty, and the alleged. Diakses Februari 2014, dari http://psycnet.apa.org/journals/amp/64/7/583/

Sugiyono. (2012). Statistika untuk Penelitian. Bandung: Alfabeta.

Sugiyono, P. D. (2013). Metode Penelitian Bisnis (Pendekatan Kuantitatif, Kualitatif dan R\&D). Bandung: Alfabeta.

Sukaesih, A. (2001). Peran ayah dalam pengasuhan serta hubungannya dengan tingkat perkembangan kemandirian dan sosial anak prasekolah di taman kanak-kanak. Diakses Maret 2, 2014, dari https://www.academia.edu/3454313/peran_ayah_dalam_pe ngasuhan_serta_hubungannya_dengan_tingkat_perkemban gan_kemandirian_dan_sosial_anak Prasekolah di Taman Kanak-kanak

Surya, P. D. (2001). Bina Keluarga. Bandung: Aneka Ilmu.

Susilowati, K. (2011). Hubungan konformitas teman sebaya dan konsep diri denga kemandirian remaja panti asuhan muhammadiyah karangayar. Diakses Mei 2014, dari http://candrajiwa.psikologi.fk.uns.ac.id/index.php/candraji wa/article/ download/22/12

Syaifuddin, M., Turatmiyah, S., \& Yahanan, A. (2013). Hukum Perceraian. Jakarta Timur: Sinar Grafika.

Yusuf, H. (2004). Psikologi Perkembangan Anak \& Remaja. Bandung: PT Remaja Rosdakarya Offset.

Zahroh, N. (2005, September). konflik need remaja yang diasuh orang tua tunggal. Diakses Desember 29, 2013, dari http://ejournal.umm.ac.id/

index.php/humanity/article/view/804/838 